ISSN 1678-3921

Journal homepage: www.embrapa.br/pab

For manuscript submission and journal contents, access: www.scielo.br/pab

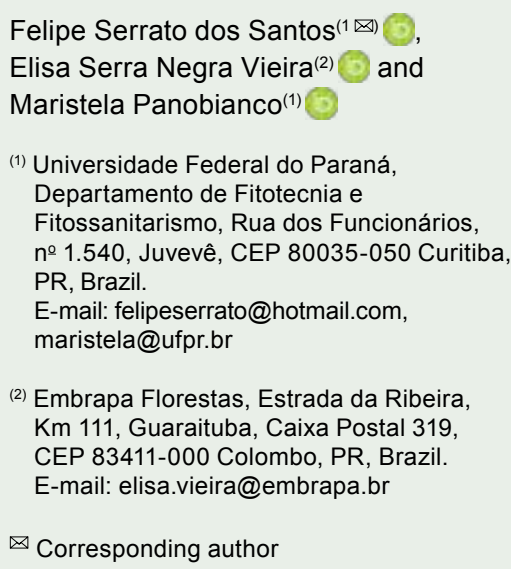

(2) Embrapa Florestas, Estrada da Ribeira Km 111, Guaraituba, Caixa Postal 319 , CEP 83411-000 Colombo, PR, Brazil. E-mail: elisa.vieira@embrapa.br

$\bowtie$ Corresponding author

Received

October 10, 2018

Accepted

August 5, 2019

How to cite

SANTOS, F.S. dos; VIEIRA, E.S.N.; PANOBIANCO, M. Tetrazolium test for Pinus taeda: preparation, staining, and seed viability classes. Pesquisa Agropecuária Brasileira, v.54, e01088, 2019. DOI: https://doi. org/10.1590/S1678-3921.pab2019.v54.01088.

\section{Tetrazolium test for Pinus taeda: preparation, staining, and seed viability classes}

\begin{abstract}
The objective of this work was to evaluate preparation and staining methods used in the tetrazolium test for Pinus taeda seeds, with the definition of viability classes. The procedures carried out were those described in the rules for seed testing in Brazil and Association of Official Seed Analysts, as well as an alternative method for the tetrazolium test. For each procedure, different combinations of types of seed cuts, concentrations of tetrazolium salt, and exposure periods were used. The test conducted with the alternative procedure (longitudinal cut adjacent to the embryo and staining of only the half with the embryo) is the most practical. The obtained results allowed classifying seeds into two different viability classes (viable and nonviable), and $0.2 \%$ tetrazolium salt for 4 hours is the most effective combination.
\end{abstract}

Index terms: germination, Pinaceae, physiological quality.

\section{Teste de tetrazólio para Pinus taeda: preparo, coloração e classes de viabilidade das sementes}

Resumo - O objetivo deste trabalho foi avaliar métodos de preparo e coloração usados no teste de tetrazólio para sementes de Pinus taeda, com definição de classes de viabilidade. Foram realizados os procedimentos descritos nas regras para análise de sementes no Brasil e na Association of Official Seed Analysts, além de um método alternativo para o teste de tetrazólio. Para cada procedimento, foram utilizadas diferentes combinações de cortes da semente, concentrações do sal de tetrazólio e tempo de exposição. O teste conduzido com o procedimento alternativo (corte longitudinal adjacente ao embrião e coloração somente da metade que contém o embrião) apresenta a maior praticidade. Os resultados obtidos permitiram classificar as sementes em duas classes de viabilidade (viável e não viável), e $0,2 \%$ de sal de tetrazólio por 4 horas é a combinação mais eficiente.

Termos para indexação: germinação, Pinaceae, qualidade fisiológica.

Due to the difficult rooting of Pinus taeda L. seedlings and the higher cost of obtaining them by vegetative propagation, their multiplication occurs mainly through sexual propagation, which makes seed technology essential to the production process of the species.

For the P. taeda germination test, the rules for seed testing in Brazil (Brasil, 2009) recommend pre-cooling at $3-5^{\circ} \mathrm{C}$ for 21 days, with a subsequent transfer to $22^{\circ} \mathrm{C}$. The final count of normal seedlings should be carried out on the twenty-eighth day after pre-cooling, which may extend in up to 50 days the period necessary to obtain the results for seed lot viability. 
Compared with the germination test, the tetrazolium test stands out since it is a biochemical method that estimates the viability of seed samples more quickly, especially of those that show dormancy (Marcos-Filho, 2015). In P. taeda seeds, different procedures are used for this test. The rules for seed testing in Brazil (Brasil, 2009) recommend staining with $1.0 \%$ tetrazolium salt, at $30^{\circ} \mathrm{C}$, for a period of 36 hours to obtain the results; for this, two cuts should be done: the first in pre-staining and the second before the assessment. The Association of Official Seed Analysts (Baalbaki et al., 2009), however, recommends only one cut before staining and quite variable periods of staining, from 4 to 16 hours, with $1.0 \%$ tetrazolium salt, at $35^{\circ} \mathrm{C}$.

Despite this, there are still few known studies on the tetrazolium test specifically for Pinus species (Savonen, 1999; Daws et al., 2006). Characterizing specific quality classes, illustrating the staining patterns for viable and nonviable seeds, and describing the vital areas to be considered during the interpretation of results would contribute to a greater diffusion of the method for the species.

The methodological adjustment of the tetrazolium test for each species is necessary since seeds differ regarding their morphological characteristics and chemical compositions (Abbade \& Takaki, 2014; Silva et al., 2016; Masullo et al., 2017). It is important to adapt a methodology to $P$. taeda, aiming to facilitate the exposure of tissues prior to staining and to define an appropriate period of staining, considering the different procedures recommended by Brasil (2009) and Baalbaki et al. (2009).

The objective of this work was to evaluate preparation and staining methods used in the tetrazolium test for Pinus taeda seeds, with the definition of viability classes.

The research was conducted in the laboratory of seed analysis of the Department for Crop Science and Disease Control of Universidade Federal do Paraná, located in Curitiba, in the state of Paraná, Brazil. Seeds from a lot of $P$. taeda, supplied by the Klabin company (Telêmaco Borba, PR, Brazil), were used in the study. The seed sample was initially homogenized and subdivided into four subsamples, composing the statistical replicates, which were stored at $17 \pm 2^{\circ} \mathrm{C}$ and $50-60 \%$ relative humidity. Seed water content was determined by the greenhouse method at $105 \pm 3^{\circ} \mathrm{C}$ for 24 hours, with two replicates of 5-g each. The result was expressed as percentage on a wet basis (Brasil, 2009). Seeds were, then, evaluated by the germination and tetrazolium tests, described as follows.

In the germination test, four replicates of 50 seeds each were sown in plastic boxes (Brasil, 2009), which were kept in a Mangelsdorf-type germinator (De Leo Equipamentos Laboratoriais, Porto Alegre, RS, Brazil) with a constant temperature of $22^{\circ} \mathrm{C}$ in the presence of light. The assessments were performed daily, with the first and last counts on the seventh and twentyeighth day after sowing, respectively, according to the criteria established in the rules for seed testing in Brazil (Brasil, 2009).

For the tetrazolium test, seeds were: pre-conditioned; immersed directly into $50 \mathrm{~mL}$ water in a $100-\mathrm{mL}$ glass beaker, incubated in biological oxygen demand, at $20^{\circ} \mathrm{C}$, for 18 hours (Brasil, 2009); and prepared and stained.

For preparation and staining, three procedures were tested. The first is recommended by the rules for seed testing in Brazil (Brasil, 2009). A transversal cut was made at one third from the endosperm distal end to open the embryo cavity to prepare for staining (Figure $1 \mathrm{~A}$ and $\mathrm{B}$ ), followed by a longitudinal cut through the endosperm to expose the embryo, removing the integument, to prepare for the subsequent assessment. Staining was performed by immersing the seeds in $1.0 \%$ tetrazolium solution for 18 hours, at $30^{\circ} \mathrm{C}$, in the dark.

The second procedure is recommended by Baalbaki et al. (2009). A longitudinal cut was made adjacent to the embryo (Figure $1 \mathrm{C}$ ), leaving sufficient tissue intact to hold the two halves of the seed together (Figure $1 \mathrm{D}$ ). Staining was carried out in a $1 \%$ tetrazolium solution for 4 hours, at $35^{\circ} \mathrm{C}$, in the dark.

The third one is an alternative procedure. A longitudinal cut was made adjacent to the embryo to expose it without the need to remove the integument. Only the half containing the embryo was stained (Figure $1 \mathrm{E}$ ) and immersed in $6 \mathrm{~mL}$ tetrazolium solution at the concentrations of $0.2,0.5$, and $1.0 \%$, combined with periods of 2,4 , and 6 hours, at $35^{\circ} \mathrm{C}$, in the dark.

After each staining period, seeds were double washed in a container with water, in a sieve, in order to avoid discarding the embryo in running water. A stereoscopic microscope, coupled to a photographic camera, was used to assess seed viability. Seeds were classified into 
two quality classes (viable and nonviable), as well as according to staining and the proportion of damages in vital areas, considering the endosperm and embryo (cotyledon, hypocotyl, and radicle). The obtained result was expressed as percentage of viability. The experimental design was completely randomized with four replicates. Means were compared by the ScottKnott test, at $1 \%$ probability. The data of water content were not analyzed statistically.

The initial seed water content was $8.7 \%$, and $P$. taeda seeds were considered small and classified as orthodox in relation to storage.

Seeds were considered viable when they showed: intense red color in the endosperm and embryo, i.e., in the cotyledon and embryonic axis (Figure $2 \mathrm{~A}$ ); carmine red color along the endosperm and embryo (Figure 2 B); carmine red color with a less intense tonality (Figure $2 \mathrm{C}$ ); light-red color with transparent
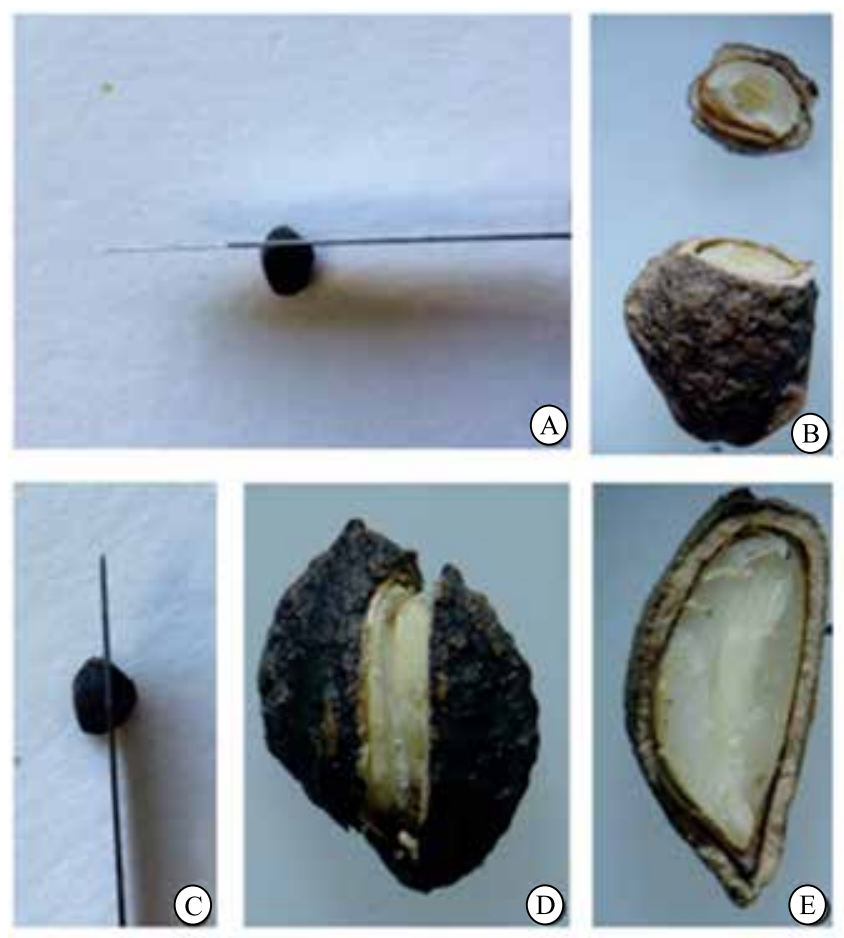

Figure 1. Types of cuts performed on Pinus taeda seeds: $\mathrm{A}$ and $\mathrm{B}$, transversal cut at the distance of one third from the endosperm distal end; $\mathrm{C}$, longitudinal cut through the endosperm to expose the embryo; $\mathrm{D}$, longitudinal cut adjacent to the embryo, keeping the two halves of the seed together; and E, longitudinal cut adjacent to the embryo, separating half of the seed containing the embryo.

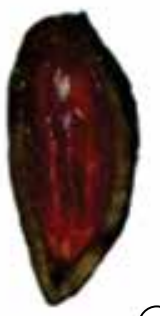

(A)

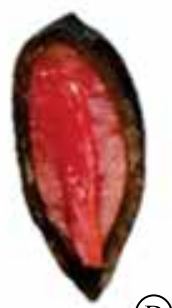

(D)

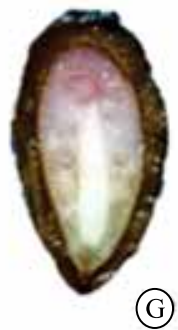

(G)

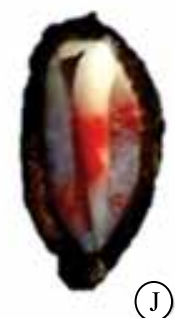

(J)

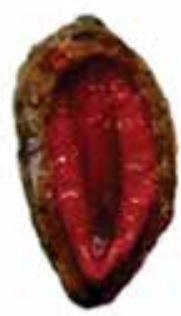

(B)

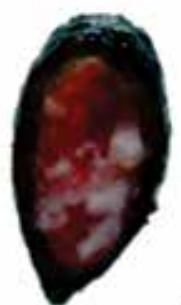

(E)

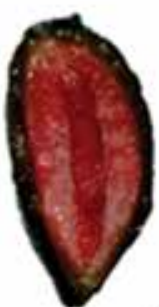

(C)

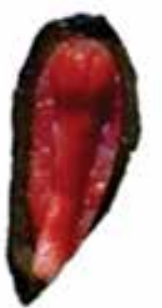

(F)

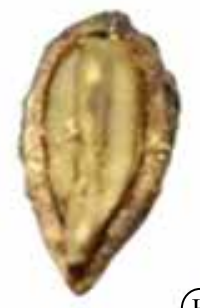

(H)
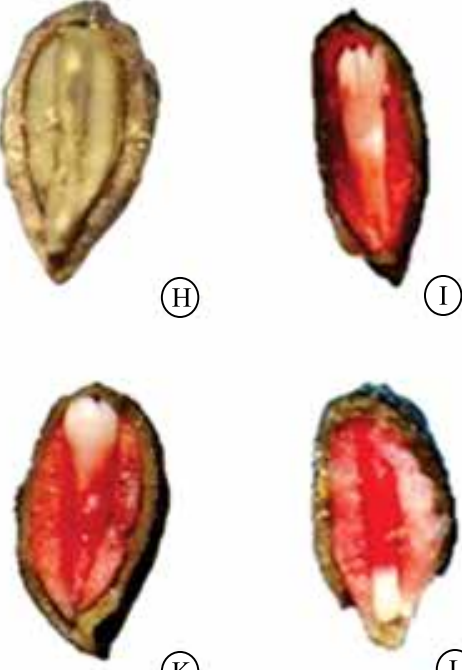

(

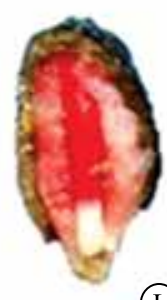

(L)

Figure 2. Classes of viable Pinus taeda seeds, showing: A, intense red color in the endosperm and embryo; B, carmine red color along the endosperm and embryo; $\mathrm{C}$, carmine red color with a less intense tonality; D, light-red color with transparent spots on the endosperm, not affecting the embryo; E, light-red endosperm and embryo with flaccid tissue; and F, carmine red embryo with small light-red spots on the embryonic axis. Classes of nonviable seeds, showing: $\mathrm{G}$, endosperm and embryo with whitish color; $\mathrm{H}$, seeds that did not color after the process of exposure to tetrazolium salt; I, most of the embryonic axis uncolored and with small colored spots; J, red spots on the endosperm and hypocotyl region; K, uncolored cotyledons; and $\mathrm{L}$, uncolored radicle tip. 
spots on the endosperm, not affecting the embryo (Figure $2 \mathrm{D}$ ); light-red colored endosperm and embryo with flaccid tissue (Figure $2 \mathrm{E}$ ); and carmine red embryo with small light-red spots on the embryonic axis (Figure $2 \mathrm{~F}$ ).

Seeds were considered nonviable when they showed: endosperm and embryo with a whitish color (Figure $2 \mathrm{G}$ ), no color after the process of exposure to tetrazolium salt (Figure $2 \mathrm{H}$ ), most of the embryonic axis uncolored and with small colored spots (Figure 2 I), red spots on the endosperm and hypocotyl region (Figure $2 \mathrm{~J}$ ), uncolored cotyledons (Figure $2 \mathrm{~K}$ ), and uncolored radicle tip (Figure $2 \mathrm{~L}$ ).

The percentage of germination was $77 \%$ (Table 1), within the standard for commercializing seeds of the species, which is $770 \%$ (Brasil, 1984). Moreover, the results of the germination test did not differ statistically from those of the following six combinations used for the tetrazolium test: $0.2 \%$ for 4 hours, $0.5 \%$ for 6 hours, and $1 \%$ for 4 and 6 hours, at $35^{\circ} \mathrm{C}$, for the alternative procedure; $1 \%$ for 4 hours, at $35^{\circ} \mathrm{C}$, for the procedure recommended by Baalbaki et al. (2009); and 1.0\% for 18 hours, at $30^{\circ} \mathrm{C}$, for the procedure recommended by the rules for seed testing in Brazil (Brasil, 2009).

Regarding the cuts made to the seeds, the rules for seed testing in Brazil (Brasil, 2009) recommend one cut before staining and another before the assessment; after 18 hours, an additional period is required for the latter in pre-conditioning and staining, making this procedure impractical for the routine laboratory analysis. Although the Baalbaki et al. (2009) methodology is easier due to the recommendation of a single longitudinal cut adjacent to the embryo, it is difficult for the analyst to keep the two halves of the seed together during the cut, resulting in a great amount of material being discarded before staining and in the need to subject a larger number of seeds to pre-conditioning. In the alternative procedure, a longitudinal cut is made adjacent to the embryo to expose it without the need to remove the integument, and only the half containing the embryo is stained, while the other one is discarded. The advantages of this procedure are the ease and speed of the proposed cut, whereas its only inconvenience is the greater difficulty of washing seeds after staining, leading to the separation of the embryo from the endosperm cavity; however, this problem was efficiently circumvented during double washing by maintaining, on the cut, the flaccid tissue surrounding the embryo (Figure $2 \mathrm{D}$ ) and easily removing it before the assessment.

The alternative procedure also shows statistically the same results of the germination test at the $0.2,0.5$, and $1.0 \%$ tetrazolium concentrations. The combination of $0.2 \%$ and 4 hours stands out, providing a perfect coloration of the seeds, which facilitates the analysis and the interpretation of results, also reducing the implementation period. Lower concentrations are more indicated because of their lower salt costs and because they allow a better visualization of the coloration disorders and the identification of the different types

Table 1. Viability of Pinus taeda seeds when subjected to the germination test and to the tetrazolium test with different combinations of methodologies ${ }^{(1)}$.

\begin{tabular}{|c|c|}
\hline Assessment & Viability $(\%)$ \\
\hline Germination test & $77 \mathrm{a}$ \\
\hline \multicolumn{2}{|l|}{$\begin{array}{l}\text { Tetrazolium test } \\
\quad \text { Procedure/cut/concentration/exposure period/temperature }\end{array}$} \\
\hline Alternative/longitudinal cut discarding one of the halves $/ 0.2 \% / 4$ hours $/ 35^{\circ} \mathrm{C}$ & $74 \mathrm{a}$ \\
\hline Alternative/longitudinal cut discarding one of the halves $/ 1.0 \% / 4$ hours $/ 35^{\circ} \mathrm{C}$ & $74 \mathrm{a}$ \\
\hline Baalbaki et al. (2009)/longitudinal cut keeping the two halves together $/ 1.0 \% / 4$ hours $/ 35^{\circ} \mathrm{C}$ & $80 \mathrm{a}$ \\
\hline Alternative/longitudinal cut discarding one of the halves $/ 0.5 \% / 6$ hours $/ 35^{\circ} \mathrm{C}$ & $73 \mathrm{a}$ \\
\hline Alternative/longitudinal cut discarding one of the halves $/ 1.0 \% / 6$ hours $/ 35^{\circ} \mathrm{C}$ & $73 \mathrm{a}$ \\
\hline Brasil (2009)/transversal and longitudinal cuts $/ 1.0 \% / 18$ hours $/ 30^{\circ} \mathrm{C}$ & $72 \mathrm{a}$ \\
\hline Alternative/longitudinal cut discarding one of the halves $/ 1.0 \% / 2$ hours $/ 35^{\circ} \mathrm{C}$ & $69 b$ \\
\hline Alternative/longitudinal cut discarding one of the halves $/ 0.5 \% / 4$ hours $/ 35^{\circ} \mathrm{C}$ & $68 \mathrm{~b}$ \\
\hline Alternative/longitudinal cut discarding one of the halves $/ 0.2 \% / 6$ hours $/ 35^{\circ} \mathrm{C}$ & $67 \mathrm{~b}$ \\
\hline Alternative/longitudinal cut discarding one of the halves $/ 0.2 \% / 2$ hours $/ 35^{\circ} \mathrm{C}$ & $63 \mathrm{c}$ \\
\hline Alternative/longitudinal cut discarding one of the halves $/ 0.5 \% / 2$ hours $/ 35^{\circ} \mathrm{C}$ & $57 \mathrm{c}$ \\
\hline Coefficient of variation (\%) & 6.10 \\
\hline
\end{tabular}

${ }^{(1)}$ Means followed by equal letters do not differ by the Scott-Knott test, at $1 \%$ probability. 
of injuries (Baalbaki et al., 2009). It should be noted that the coloration periods of 2 and 4 hours, at the concentration of $0.5 \%$, were insufficient to estimate the viability of $P$. taeda seeds because they did not promote an adequate coloration to distinguish living from dead or damaged tissues. It was also observed that the 2-hour coloration period associated with concentrations of 0.2 and $1.0 \%$ did not develop optimal coloration and provided different results from those obtained in the germination test, indicating that this period was also insufficient to estimate seed viability.

The obtained results show that, among treatments, the alternative seed cutting procedure presented the best performance in terms of practicality of the tetrazolium test. Because the seed of P. taeda has a hard integument, the execution of only one cut facilitates the analysis and the thin membrane left on the embryo can be easily discarded during washing, making this procedure quite promising. In addition, for $P$. taeda seeds, the assessment of the color of the endosperm and not only of the embryo is important for interpreting the tetrazolium test because of the role of this reserve tissue in providing nutrients to the embryo in the germination process (Costa et al., 2011).

The choice of the most appropriate method for the tetrazolium test must be based on the facility of identifying viable and nonviable tissues (Azerêdo et al., 2011). Through different combinations of seed cutting, exposure periods, and concentrations of tetrazolium salt, it was possible to adapt an efficient and fast methodology for P. taeda seeds, performing only a longitudinal cut adjacent to the embryo and reducing the period of exposure of the seeds to tetrazolium salt and its concentrations.

Therefore, the tetrazolium test conducted with the alternative procedure is more practical for P. taeda seeds. The obtained results allowed establishing two different viability classes (viable and nonviable), and $0.2 \%$ tetrazolium salt for 4 hours is an effective combination to assess seed viability.

\section{Acknowledgment}

To Coordenação de Aperfeiçoamento de Pessoal de Nível Superior (Capes), for scholarship granted.

\section{References}

ABBADE, L.C.; TAKAKI, M. Teste de tetrazólio para avaliação da qualidade de sementes de Tabebuia roseoalba (Ridl.) Sandwith - bignoniaceae, submetidas ao armazenamento. Revista Árvore, v.38, p.233-240, 2014. DOI: https://doi.org/10.1590/S010067622014000200003 .

AZERÊDO, G.A. de; PAULA, R.C. de; VALERI, S.V. Viabilidade de sementes de Piptadenia moniliformis Benth. pelo teste de tetrazólio. Revista Brasileira de Sementes, v.33, p.61-68, 2011. DOI: https://doi.org/10.1590/S0101-31222011000100007.

BAALBAKI, R.; ELIAS, S.; MARCOS-FILHO, J.; MCDONALD, M.B. (Ed.). Seed vigor testing handbook. Ithaca: Association of Official Seed Analysts, 2009. 341p. (AOSA. Contribution, 32).

BRASIL. Ministério da Agricultura, Pecuária e Abastecimento. Gabinete do Ministro. Portaria n ${ }^{\circ}$ 18, de 25 de janeiro de 1984. [Estabelece, em todo o território nacional, os padrões mínimos de qualidade de sementes florestais, das espécies pinus, eucalyptus, acacia, mimosa e araucária, especificadas]. Diário Oficial da União, 27 jan. 1984. Seção 1, p.14.

BRASIL. Ministério da Agricultura, Pecuária e Abastecimento. Regras para análise de sementes. Brasília, 2009. 395p.

COSTA, C.J.; ZIMMER, P.D.; VILLELA, F.A. Base celular da origem e desenvolvimento do endosperma. Revista Científica Rural, v.13, p.226-246, 2011.

DAWS, M.I.; COUSINS, C.; HALL, J.; WOOD, C.B. Pressuretime dependency of vacuum degassing as a rapid method for viability assessment using tetrazolium chloride: a comparative study of 17 Pinus species. Seed Science and Technology, v.34, p.475-483, 2006. DOI: https://doi.org/10.15258/sst.2006.34.2.22.

MARCOS-FILHO, J. Fisiologia de sementes de plantas cultivadas. 2.ed. Londrina: ABRATES, 2015. 659p.

MASULLO, L.S.; PIÑA-RODRIGUES, F.C.M.; FIGLIOLIA, M.B.; AMÉRICO, C. Optimization of tetrazolium tests to assess the quality of Platymiscium floribundum, Lonchocarpus muehlbergianus and Acacia polyphylla DC. seeds. Journal of Seed Science, v.39, p.189-197, 2017. DOI: https://doi.org/10.1590/2317-1545v39n2167534.

SAVONEN, E.-M. An improvement to the topographic tetrazolium testing of Scots pine (Pinus Sylvestris L.) seeds. Seed Science and Technology, v.27, p.49-57, 1999.

SILVA, B.A. da; NOGUEIRA, J.L.; VIEIRA, E.S.N.; PANOBIANCO, M. Critérios para condução do teste de tetrazólio em sementes de araucária. Pesquisa Agropecuária Brasileira, v.51, p.61-68, 2016. DOI: https://doi.org/10.1590/ S0100-204X2016000100008. 